Barbara was a scholar of note and a person of great integrity and generosity of spirit: she will be deeply missed.

Contributions in memory of Barbara Salert may be made to the Save the Children Federation, Amnesty International, Leader Dogs for the Blind, the National Hemlock Society, or the National Hospice Organization, with notification to Susan Siler, 154 Bradley Road, Scarsdale, NY 10583.

Victor Le Vine

Washington University, St. Louis

\section{William J. Siffin}

William J. Siffin, professor emeritus of political science and of public and environmental affairs at Indiana University (IU), Bloomington, died June 18, 1993. He was 71 .

During his career, Siffin became one of the best-known figures in a movement that has transferred American administrative experience to scores of developing countries around the world.

Born May 31, 1922, in Cleveland, Ohio, he was the son of William $\mathbf{J}$. and Margaret N. (Novak) Siffin.

Siffin joined the IU faculty in 1952 and retired in 1988. For several years, he represented IU in the Midwest Universities' Consortium for International Activities (MUCIA), which organizes teams of academic experts to provide technical assistance to developing countries.

From 1970-72 he took a leave from the university to serve as director of the Office of Development Administration in the Technical Assistance Bureau of the Agency for International Development (AID) in Washington, D.C.

A graduate of the IU School of Business, he holds advanced degrees from the University of Minnesota and from Harvard University.

While at IU, Siffin held the positions of director of the Institute of Training for Public Service, director of the International Development Institute, and acting dean for International Programs.

He served as an adviser and consultant on management and administration to various United Nations agencies, the Ford Foundation, the World Bank, and a number of individual foreign countries.

In Thailand he was an adviser to the Institute of Public Administration at Thammasat University, Bangkok, and was awarded the prestigious rank of commander in the Royal Order of the White Elephant, by King Bhumipol. He also worked on social development programs in Iran.

He served as an administrative staff officer and analyst for the Tennessee Valley Authority in the 1940s. From 1950-52 he was director of research for the Kentucky Legislative Research Commission.

He received the Eastern Regional Organization for Public Administration Award in 1983. In 1986, he received the first Fred Riggs Award from the Society of International Comparative Administration in honor of his contributions to the field and, a year later, won election to the National Academy of Public Administration. He was also the recipient of the John W. Ryan Award for Distinguished Contribution to International Programs and Studies at the 1991 Founder's Day commemoration at IU.

Commenting on Siffin's death, IU President Thomas Ehrlich said, "He was a wonderful scholar, teacher and friend who made a substantial contribution to the university."

Speaking on behalf of IU International Programs, Dean Alexander Rabinowitch said, "Bill preceded me as dean. He was one of the wisest and most caring people I have ever known. For all of us in the Office of International Programs, he was a constant source of encouragement and support, even after his formal retirement."

Patrick O'Meara, director of the African Studies Program and Siffin's colleague in the Department of Political Science and the School of Public and Environmental Affairs, said, "I think of him as a splendid colleague, a man of intellectual curiosity and cultural sensitivity with an incredible imagination and wit. I had the privilege to serve with him on many doctoral defenses and those moments epitomized his scholarship and humanity.

"He had enormous respect for the students, particularly those from other parts of the world who had struggled to complete their dissertations, often in other languages. His gentleness and yet his penetrating intellectual probing are all vividly etched in my mind. Bill was an example of what all scholars and academics should be."

John V. Lombardi, president of the University of Florida and formerly dean of the IU College of Arts and Sciences, added, "Graceful, brilliant and a generous spirit defined Bill Siffin for his many friends and students.

"Each of us came to Bill with our problems, our solutions, our ideas and our personal intensity. Each of us left with our understanding enhanced, our vision expanded and our spirit renewed. Not until much later did we recognize the brilliance we had encountered; not for a time did we know that we had been taught by a master. He lived for us, he gave of himself and Bill Siffin will always live through us."

$\mathrm{He}$ is survived by his wife, Catherine (Fox) Siffin, and three children, Mark Siffin, Louise Siffin, and Kelly Siffin, all of Bloomington, and three granddaughters.

He was preceded in death by his parents and one brother, Joseph Patrick Siffin.

Memorial contributions may be made to the Friends of the IU Press or the Bloomington Convalescent Center, in care of the Bloomington Hospital Foundation.

Jayne H. Spencer Indiana University Bloomington 